\title{
Using Two Retrotransposon Based Marker Systems (IRAP and REMAP) for Molecular Characterization of Olive (Olea europaea L.) Cultivars
}

\author{
Ergun KAYA ${ }^{1,2 *}$, Emel YILMAZ-GOKDOGAN ${ }^{1}$ \\ ${ }^{1}$ Mugla Sitki Kocman University, Faculty of Science, Molecular Biology and Genetics Department, Kotekli, 48000, Mugla, \\ Turkey;ergunkaya@mu.edu.tr("correspondingauthor);emelyilmaz@mu.edu.tr \\ ${ }^{2}$ Gebze Technical University, Molecular Biology and Genetics Dept, 41400, Gebze, Kocaeli, Turkey
}

\begin{abstract}
Olive (Olea europaea L.) is one of the most characteristic agricultural trees of the Mediterranean region and has a large number of cultivar diversity. Olive cultivar characterization is very important especially for the fruit productivity and olive oil quality. In the present study, 46 clones belonging to Turkey (eight cultivars, each having five clones) and Italy (two cultivars, each having three clones) were assessed for cultivar characterization via inter-retrotransposon amplified polymorphism (IRAP) and retrotransposon-microsatellite amplified polymorphism (REMAP) marker systems using $10 \mathrm{LTR}$ and 10 ISSR primers. In total, 368 band profiles were obtained, 358 of which are polymorphic ( $97.28 \%$ polymorphism). The cultivars were segregated into three main groups, each group having several branches, where all the clones of each cultivar were belonging to the same main group. The only exception to that was the distribution of the clones of cultivar Yaglik, 'Yaglik 4' and 'Yaglik 5', into different main groups. IRAP and REMAP analysis showed a high level of genetic variability among the olive cultivars in this study and this marker systems would be useful tool for clonal selection programs.
\end{abstract}

Keywords: LTRs, olive cultivar diversity, molecular marker

Abbreviation list: CTAB (Cetyl trimethyl ammonium bromide); IRAP (Inter-retrotransposon amplified polymorphism); ISSR (Inter simple sequence repeat); LTR (Long terminal direct repeat); REMAP (Retransposon-microsatellite amplified polymorphism).

\section{Introduction}

Olive (Olea europea L.) has more than 2600 cultivars, and has been cultivated since the ancient times in the Mediterranean area, where it is still the most significant oil-producing crop, the region accounts for not less than $97 \%$ of the world production and $91 \%$ of world consumption of olive oil (Luchetti, 1993; Rugini and Lavee, 1992; Zohary and Hopf, 1994). The cultivated form of olive $(O$. europaea L. var. europaea) is produced from the seedlings of wild form of olive (O. europaea L. var. sylvestris) by cutting or grafting (Green, 2002), where these two interfertile olive forms produce a large number of varieties with high levels of heterozygosity and genetic diversity among predominantly allogamus cultivars (Angiolillo et al., 1999; Diaz et al., 2006). This variability in olive cultivars makes the cultivar identification extremely difficult, which is actually crucial for the determination of olive productivity and oil quality, i.e., properties inherited to a variety (Fiorino and Rallo, 1999). In this respect, molecular markers are very useful for characterization of olive varieties and detection of synonymous and homonymous. Indeed, wide range of DNA molecular marker types have been used for genetic variability and cultivar identification of olive during the last ten years such as RAPDs (Hess et al., 2000;
Bronzini de Caraffa et al.,2002; Martins-Lopes et al., 2007; Zitoun et al., 2008; Awan et al., 2011; Figueiredo et al., 2013), AFLPs (GratiKamoun et al., 2006; Montemurro et al. 2008; Albertini et al., 2011), ISSRs (Gomes et al.2008; Martin-Lopes et al., 2009; Beikiet al.,2012),SSRs (Muzzalupo et al., 2009; Belaj et al., 2010; Corrado et al. 2011; Cicatelli et al., 2013), SNPs (Reale et al., 2006), DArTs (Atienza et al, 2013).

Retrotransposons are mobile genetic elements through the eukaryotic genomes, especially in plants, they are considered to act an important role in genome evolution (Flavell et al., 1992; Vicient et al, 2001; Giordani et al., 2004). They cover about 50\% of repetitive DNA of the whole genome in higher plants (Kumar and Bennetzen, 1999). Their unstable genomic locations, flexible copy numbers, length, described and conserved sequences provide them with an advantage to be a more specific genetic marker for plant biodiversity and genome analysis (Queen et al., 2004; Agarwal et al., 2008; Vukich et al., 2009; D’Onofrio et al., 2010; Kalendar et al., 2011). Retrotransposons can be classified into three types according to their structural organization and amino acid similarities. Copialike (Kumar et al., 1996) and gypsy-like retrotransposons (Suoniemi et al., 1998) belong to long terminal direct repeats (LTRs), they encode proteins similar to the retroviruses, and they are present over 
168

the plant kingdom. Non-LTR retrotransposons defect terminal repeats and encode proteins with significantly less similarity to those of the retroviruses (Agarwal et al., 2008).

IRAP and REMAP marker systems, in contrast to other techniques, characterize large genetic dissimilaries in the cultivars. Integration of retrotransposon creates new links between genomic DNA and their conserved ends, for this reason, they can be used as useful molecular markers. Retrotransposon-based marker systems are an important source of plant genetic diversity and this system mostly use PCR to reproduce a segment of genomic DNA at this link (Kalendar and Schulman, 2006). Therefore, genetic differentiation perseveres through the old copies, but insertion of new copies arises. The ancestral and reproduced typical locus differentiations become potential as the lack of the introduced sequence can be, with high reliance, conceived ancestral. Basicly, the presence of a fixed retrotransposon in relevant taxa recommends their orthologues integration while the lack of specific elements shows the plesiomorphic condition prior to integration in more different taxa. A phylogenetic tree of species based on the presence of retrotransposons dispersion and its irreversible facts during evolution can build this presence/absence analyses. This is why retrotransposons are accepted to show strong synapomorphies (Shedlock and Okada, 2000).

Inter-retrotransposon amplified polymorphism (IRAP), where the fragments are amplified with LTR primers while in the retrotransposon-microsatellite amplified polymorphism (REMAP), where the fragments are amplified with a LTR and an ISSR primer. Both retrotransposon-based marker systems based on the position of the given LTRs within the genome (Kalendar et al., 1999). The IRAP and REMAP marker systems have been developed essentially for BARE-I retrotransposon of barley (Kalendar et al., 2000), and both have been used to detect similarity of rice (Branco et al., 2007), Triticum (Pagnotta et al., 2009), grapevine (D’Onofrio et al., 2010), Citrus (Biwas et al., 2010), Japanese apricot (Yuying et al., 2011), potato (Sharma and Nandieni, 2014) and Hordeum (Cabo et al., 2014).

There are only few reports available on application of retrotransposon-based marker systems for molecular identification in olive. The first study, reported by Hernandez et al. (2001), presents the first evidence of a retrotransposon-like element in olive using SCAR-markers. Giordani et al. (2004) and Koksal et al. (2014) reported genetic diversity in olive cultivars using retrotransposon-based marker system, as well. They used the IRAP (Koksal et al, 2014) and REMAP (Giordini et al., 2004) marker systems for molecular characterisation of olive cultivars. These reports can be considered as the first comprehensive research, where retrotransposon-based marker technique is used on olive genome. However, these short presentations have not generated yet a published research article.

\section{Materials and Methods}

\section{Plant Material}

46 olive clones belonging to 10 olive cultivars were analysed. 8 cultivars were obtained from different cities of Turkey (Ballkesir cv. 'Edincik'; Bursa-Gemlik cv. 'Gemlik'; Hatay cv. 'Edremit'; Mardin cv. 'Halhali'; Mugla cv. 'Domat'; Samsun cv. 'Alacam'; cv. 'Tekir' and cv. 'Yaglik', obtained from Olive Research Institute, Izmir) while the other 2 (cv. 'Canino' and cv. 'Frantoio') were obtained from CNR (National Research Council) / IVALSA (Trees and Timber Institute), Italy.

\section{DNA Extraction}

The total genomic DNA was extracted by using CTAB method (Doyle and Doyle, 1987) after grinding the youngleaf tissue to a fine powder. DNA sample concentration was determined using a nanodrop spectrophotometer (BioSpec-nano; ShimadzuBiotech). DNA samples were diluted to $50 \mathrm{ng} / \mu \mathrm{l}$ prior to IRAP and REMAP PCR amplifications.

\section{IRAP (Inter-Retroelement Amplified Polymorphisms) PCR}

IRAP-PCR DNA amplification was performed using 10 IRAP primers (LTR 1-13; Smykal et al., 2011; Table 1). Amplifications were performed according to Kalendar et al. (2011) in a $25 \mu \mathrm{l}$ reaction volume, containing PCR Buffer ( $1 \mathrm{x}$ final concentration, invitrogen), 2,5 $\mathrm{mM} \mathrm{MgCl}_{2}, 0,4 \mathrm{mM}$ of each dNTP, 0,4 mM IRAP primer, 50 ng genomic DNA, and 2 unit Taq DNA polymerase. Amplification conditions (thermocycler Model-9700, PerkinElmer, Boston, MA, USA) were as follows: initial denaturation at 95 ${ }^{\circ} \mathrm{C}$ for $3 \mathrm{~min}, 35$ cycles at $95^{\circ} \mathrm{C}$ for $15 \mathrm{sec}, 55^{\circ} \mathrm{C}$ for $30 \mathrm{sec}$, a ramp to $72{ }^{\circ} \mathrm{C}$ reaching in $3 \mathrm{~min}$, followed by a $10 \mathrm{~min}$ lag at this temperature, and an indefinite holding at $4{ }^{\circ} \mathrm{C}$, respectively. Amplicons were separated on $1.5 \%$ agarose gel at $80 \mathrm{~V}$. They were then stained with $0.5 \mu \mathrm{g} / \mathrm{ml}$ ethidium bromide solution, visualized by illumination under UV light, and documented using a gel documentation and image analysis system (BIORAD, Molecular Imager, ChemiDocTMXRS+ with Image LabTM Software).

\section{REMAP (Retrotransposon-Microsatellite Amplified Polymorphism) PCR}

REMAP-PCR DNA amplification was performed using a combination of $10 \mathrm{LTR}$ primers $(0.2 \mathrm{mM}$ for each reaction) and 10 ISSR primers, each primer at the concentration of $0.2 \mathrm{mM}$ for each reaction (Martins-Lopes et al., 2009; Smykal et al., 2011; Table 2). Amplification conditions and separating were the same as for IRAP PCRs (see above). DNA fragments of IRAP and REMAP PCRs were scored by their presence (1) or absence ( 0 ), and the ones at low intensities were scored only if they were reproducible in both the PCR runs. Cluster analysis was performed to construct dendrograms, with the unweighted pair-group method by arithmetic averages (UPGMA) from the similarity data matrices using Jaccard's coefficient (D-UPGMA, 2002).

\section{Results and Discussion}

Molecular fingerprinting of forty six clones belonging to ten cultivars was carried out using IRAP and REMAP analysis, and very high polymorphism (97.28\%, in average) was detected by both the methods. The total of 368 reproducible bands, ranging from 125 to 3600 bp, were scored. 126 bands were obtained by IRAP and 242 were by REMAP techniques, with a similar polymorphism rates of 96.82\% (122 polymorphic bands) and 97.52\% (236 polymorphic bands), respectively. The highest polymorphism rate was obtained by REMAP PCR 2 amplification, and produced 23 polymorphic bands (Fig. 1).

The dendrogram of 46 clones belong to 10 olive cultivars amplified by the IRAP markers is shown in Fig. 2. The genetic similarities ranged from 0,013 (between Y1 cv. 'Yaglik' and T4T5 cv. 'Tekir'; between $\mathrm{H} 1$ and $\mathrm{H} 2 \mathrm{cv}$. 'Edremit') to 0,75 (between B1 cv. 'Edincik' and S1 cv. 'Alacam'), while T3 and T4 cv. 'Tekir' were shown to be similar. The cultivars were grouped into eight clusters; Cluster I, B1-5, (Balikesir cv. 'Edincik'); Cluster II, G1-5 (BursaGemlik cv. 'Gemlik'), H1-5 (Hatay cv. 'Edremit'); Cluster III, Ma 


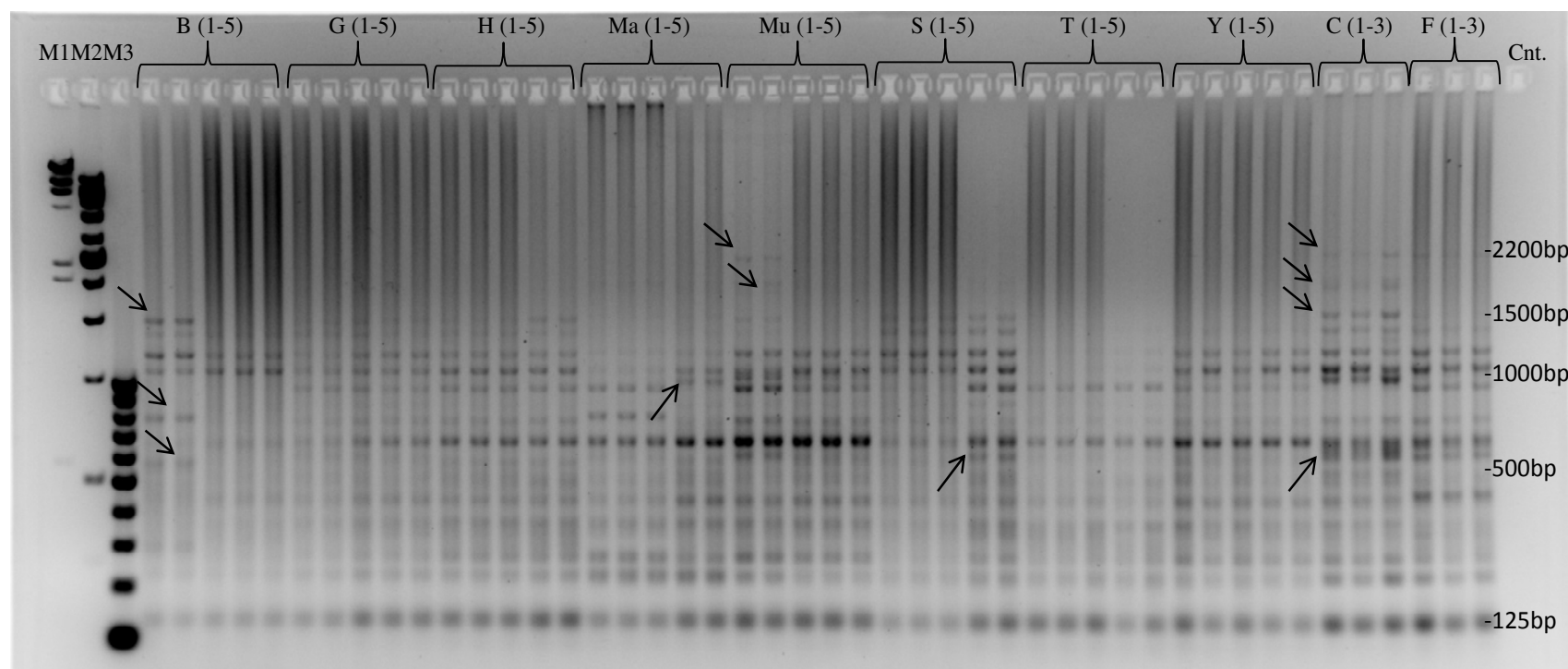

Fig. 1. REMAP 2 amplification products obtained in 1,5\% agarose gel from fourty-six clones belong to ten olive cultivars with LTR 1 primer and ISSR 2 [B, 'Burhaniye'; G, 'Gemlik'; H, 'Hatay'; Ma, 'Mardin'; Mu, 'Mugla'; S, 'Samsun'; T, 'Tekir'; Y, 'Yaglik'; C 'Canino' and F 'Frantoio'; M1, Lambda DNA/Hind III marker (vivantis); M2, 1kbladder (GeneRuler $\left.{ }^{\mathrm{TM}}\right)$, M3, 100bp ladder (GeneRuler $\left.{ }^{\mathrm{TM}}\right)$; Cnt. (- Control), Some of polymorphic band profiles were shown with arrows]

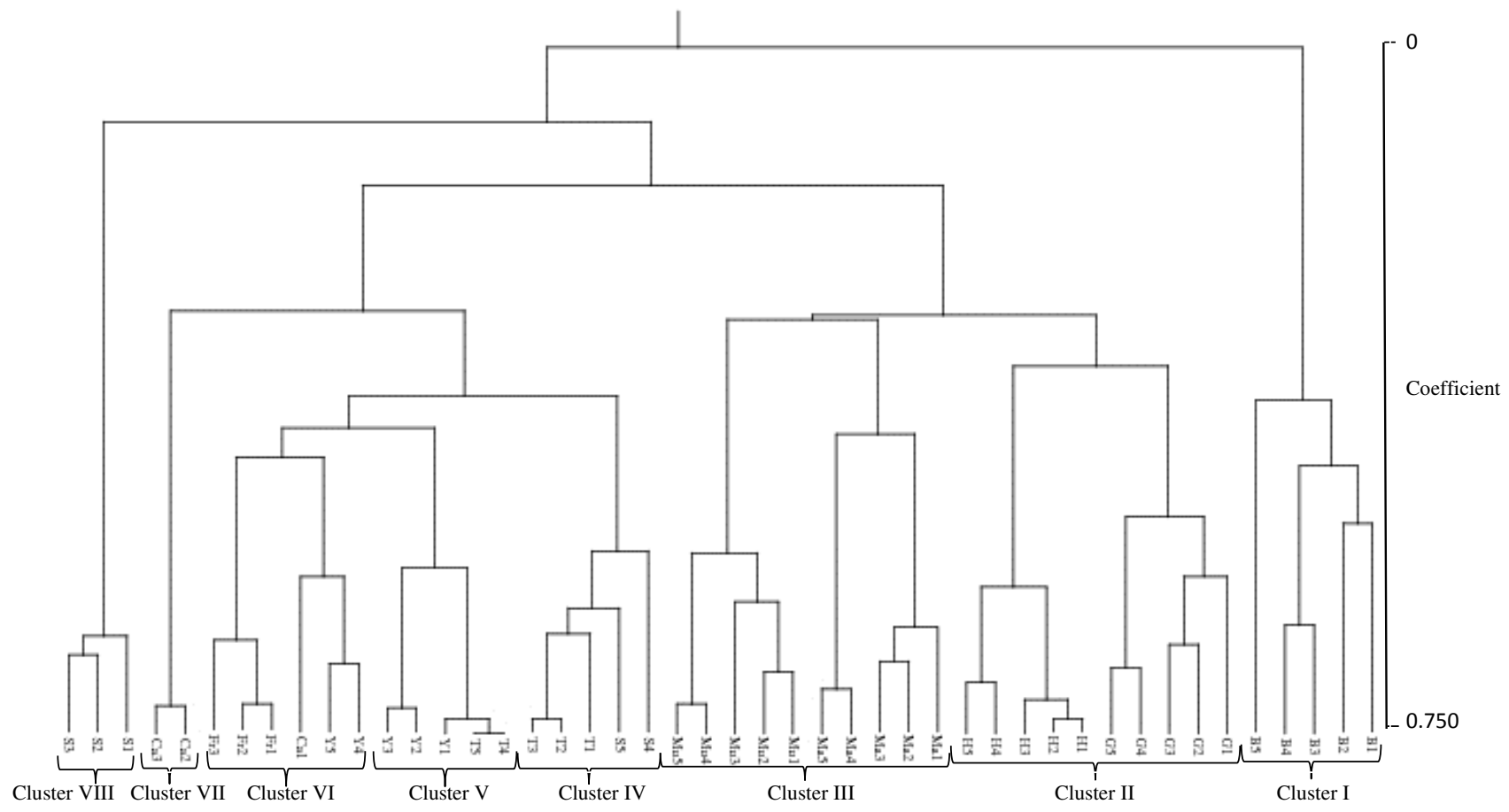

Fig 2. UPGMA dendrogram based on Jaccard's coefficient illustrating the genetic similarities and distance among olive cultivars obtained by IRAP data, generated by the UPGMA cluster analysis (NTSYS). Cluster I, B1-5, (Balkesir cv. 'Edincik'); Cluster II, G1-5 (Bursa-Gemlik cv. 'Gemlik'), H1-5 (Hatay cv. 'Edremit'); Cluster III, Ma 1-5 (Mardin cv. 'Halhali'), Mu 1-5 (Mugla cv. 'Domat'); ClusterIV,S45 (Samsun cv. 'Alacam'), T1-3 (cv. 'Tekir'); ClusterV,T45 (cv. Tekir'), Y1-3 (cv. 'Yagilik'); ClusterVI, Y45 (cv. 'Yagik'), Cal (cv.'Canino'), Fr1-3 (cv.' Frantoio'); Cluster VII, Cal-3 (cv. 'Canino') and ClusterVIII,S1-3(Samsuncv.'Alacam')

1-5 (Mardin cv. 'Halhali'), Mu 1-5 (Mugla cv. 'Domat'); Cluster IV, S45 (Samsun cv. 'Alacam'), T1-3 (cv. 'Tekir'); Cluster V, T45 (cv. 'Tekir'), Y1-3 (cv. 'Yaglik'); Cluster VI, Y45 (cv. 'Yaglik'), Cal (cv. 'Canino'), Fr1-3 (cv. 'Frantoio'); Cluster VII, Ca2-3 (cv. 'Canino') and Cluster VIII, S1-3 (Samsun cv. 'Alacam'). However, each cluster divided into some sub-clusters, for example Cluster II and III divided into two sub-clusters (Fig. 2). On the other hand, according to the dendrogram of the REMAP markers, the cultivars were grouped into five clusters (Fig. 3; Cluster I, B1-5, (Balkesir cv. 'Edincik');
Cluster II, G1-5 (Bursa-Gemlik cv. 'Gemlik'), H1-5 (Hatay cv. 'Edremit'); Cluster III, Ma 1-5 (Mardin cv. 'Halhali'), Mu 1-5 (Mugla cv. 'Domat'); Cluster IV, S1-5 (Samsun cv. 'Alacam'), T1-5 (cr. 'Tekir'), Y1-3 (cr. 'Yaglik') and Cluster V, Y45 (cv. 'Yaglik'), Cal-3 (cv. 'Canino'), Frl-3 (cv. 'Frantoio'). The genetic similarities ranged from 0,054 (between Ma3 and Ma cv. 'Halhali') to 0,735 (between B1 cv. 'Edincik' and H2 cr. 'Edremit'). However, each cluster divided into some sub-clusters, for example, Cluster II, III and $I V$ divided into three sub-clusters (Fig. 3). 
170

Genetic similarities/varieties were obtained with combined (IRAP and REMAP) UPGMA algorithm using Jaccard's coefficient (Fig. 4). The genetic similarities ranged from 0,068 (Ma 1 - Ma 2, Mardin cv. 'Halhali') to 0,705 (B1, Ballkesir cv. 'Edincik' S1, Samsun cv. 'Alacam'). The cultivars were grouped into four major clusters; Cluster I, B1-5, (Balıkesir cv. 'Edincik'); Cluster II, G15 (Bursa-Gemlik cv. 'Gemlik'), H1-5 (Hatay cv. 'Edremit'), Ma 1-5 (Mardin cv. 'Halhali'), Mu 1-5 (Mugla cv. 'Domat'); Cluster III,S1-5 (Samsun cv. 'Alacam'), T1-5 (cv. 'Tekir'), Y1-3 (cv. 'Yaglik') and
Cluster IV, Y45 (cv. 'Yaglik'), Ca1-3 (cv. 'Canino'), Fr1-3 (cv. 'Frantoio'). However, each cluster divided into some sub-clusters, for example Cluster $I$ and $I V$ divided into two sub-clusters, Cluster II divided into four sub-clusters, Cluster III divided into three subclusters (Fig. 4).

Some close relationships between cultivars were constant in all IRAP and REMAP analyses performed; for instance, cv. 'Gemlik' and cv. 'Edremit' (similarity ranges from 0.393 to 0.581 ); cv. 'Halhali' and 'Domat' (similarity ranges from 0.319 to 0.587 ) and Italian

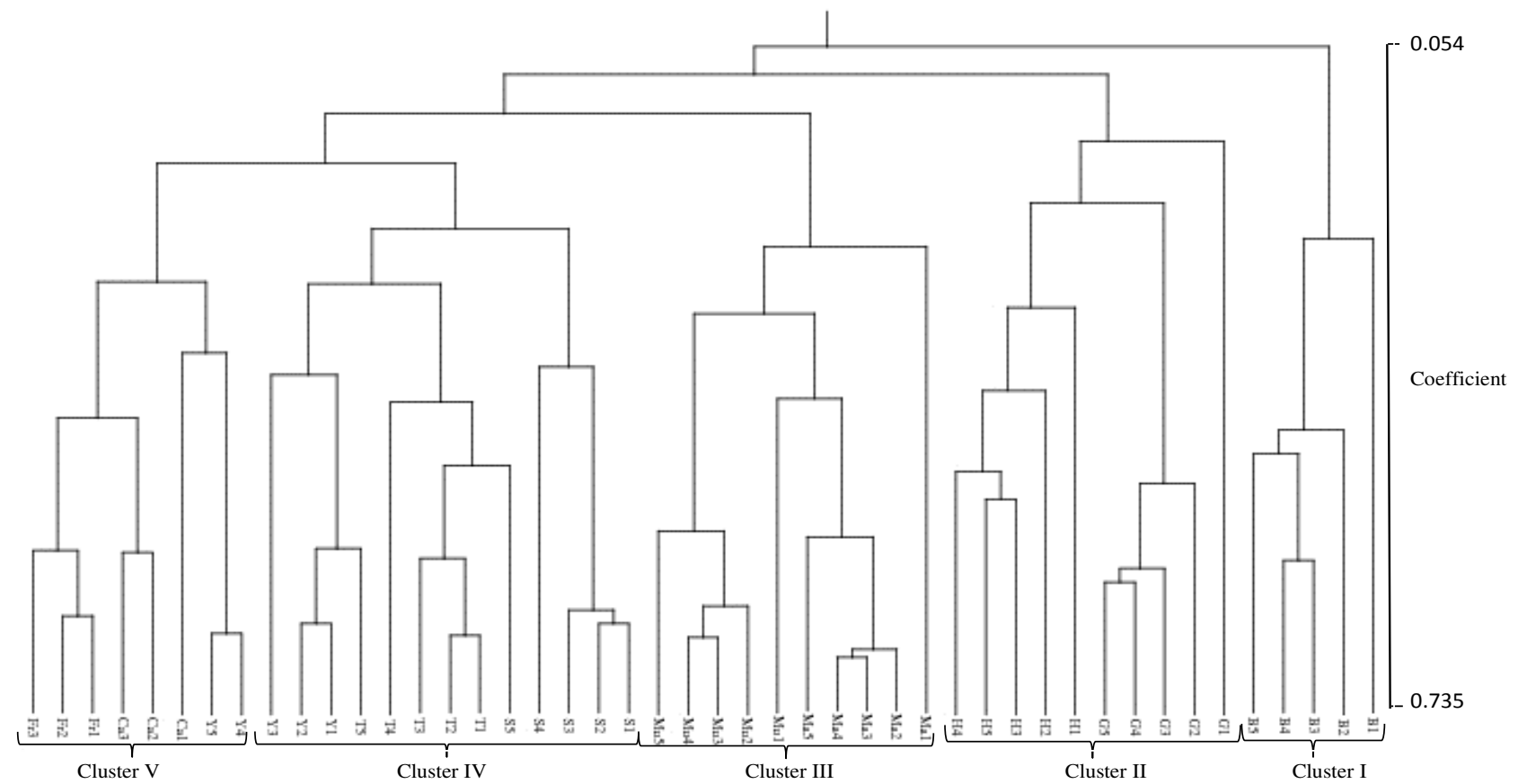

Fig. 3. UPGMA dendrogram based on Jaccard's coefficient illustrating the genetic similarities and distance among olive cultivars obtained by REMAP data, generated by the UPGMA cluster analysis (NTSYS). Cluster I, B1-5, (Balkesir cv. 'Edincik'); Cluster II, G1-5 (Bursa-Gemlik cv. ‘Gemlik'), H1-5 (Hatay cv. 'Edremit'); Cluster III, Ma 1-5 (Mardin cv. 'Halhali'), Mu 1-5 (Mugla cv. 'Domat'); ClusterIV,S1-5 (Samsun cv. 'Alacam'), T1-5 (cv. 'Tekir'), Y1-3 (cv. 'Yaglik') and ClusterV, Y45 (cv. 'Yaglik'), Cal-3 (cv. 'Canino'), Fr1-3 (cv. 'Frantoio')

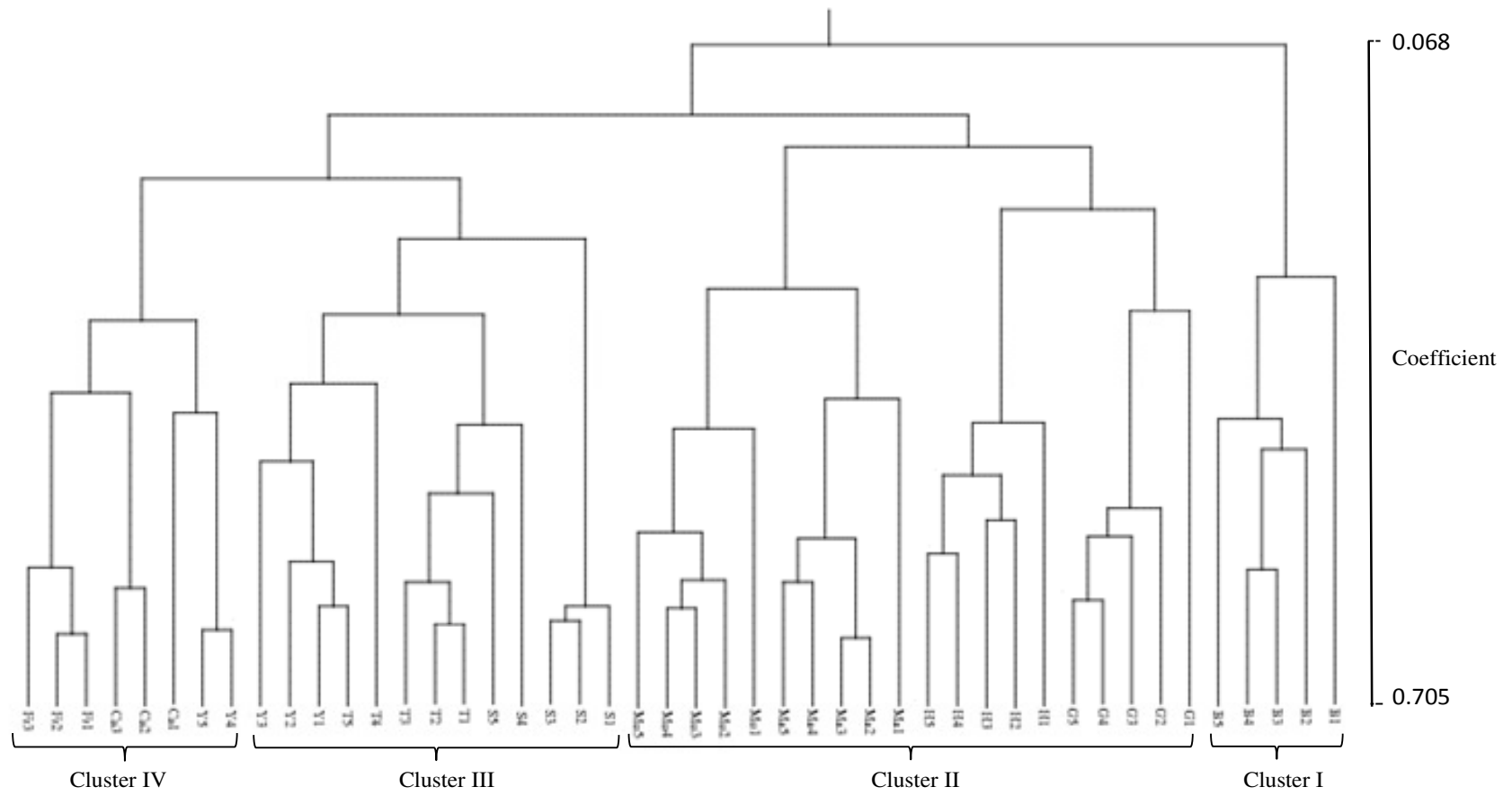

Fig. 4. UPGMA dendrogram based on Jaccard's coefficient illustrating the genetic similarities and distance among olive cultivars obtained by combined IRAP and REMAP data, generated by the UPGMA cluster analysis (NTSYS). Cluster I, B1-5, (Ballkesir cv. 'Edincik'); Cluster II, G1-5 (Bursa-Gemlik cv. 'Gemlik'), H1-5 (Hatay cv. 'Edremit'), Ma 1-5 (Mardin cv. 'Halhali'), Mu 15 (Mugla cv. 'Domat'); Cluster III, S1-5 (Samsun cv. 'Alacam'), T1-5 (cv. 'Tekir'), Y1-3 (cv. 'Yagik') and Cluster IV, Y4-5 (cv. 'Yaglik'), Cal-3 (cv. 'Canino'), Fr1-3 (cv. 'Frantoio') 


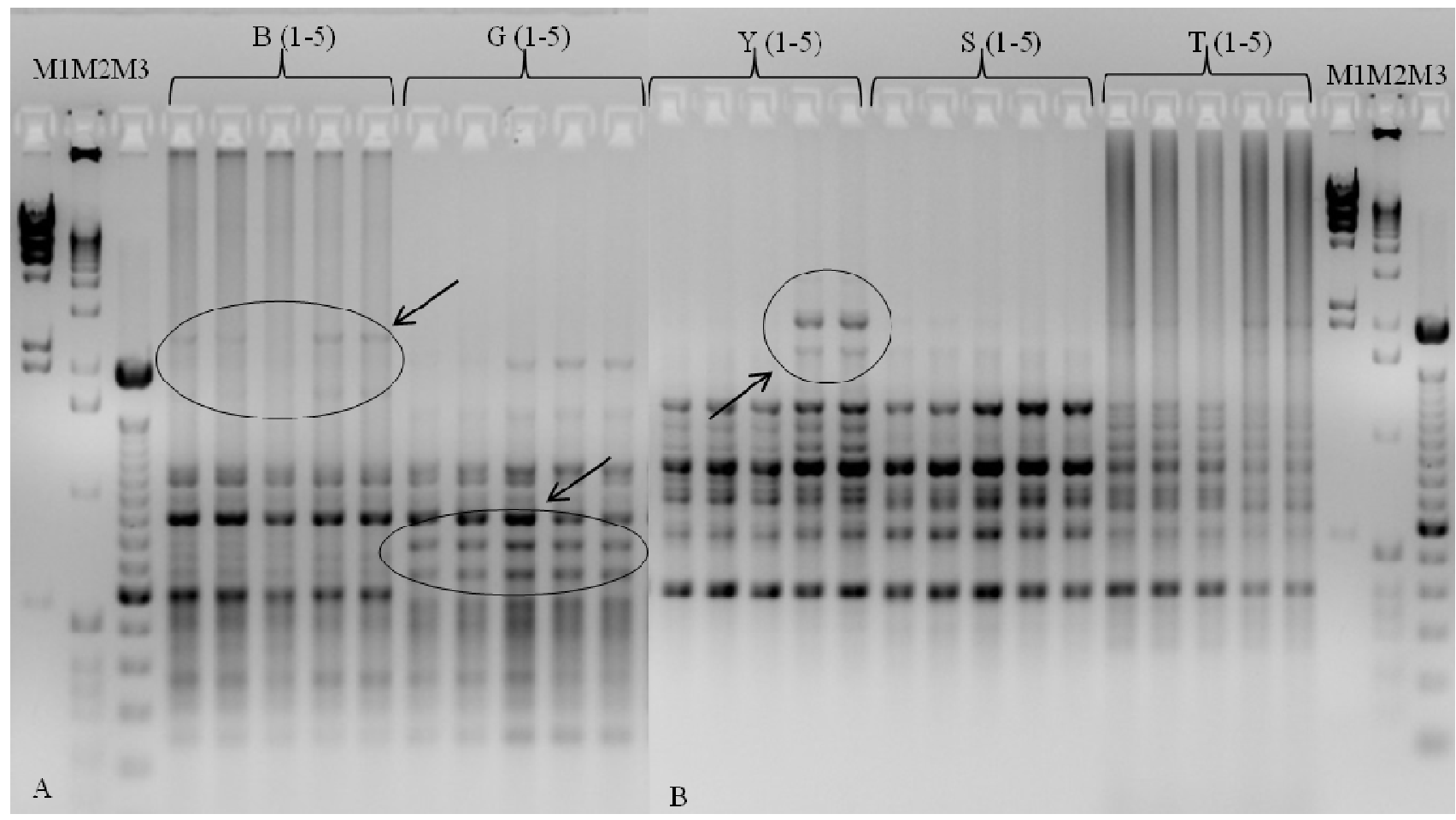

Fig. 5. REMAP 4 using LTR 1 and ISSR 4 primers (A) and IRAP 2 using LTR 2 primer (B) amplification products obtained in 1,5\% agarose gel [B, 'Burhaniye'; G, 'Gemlik'; S, 'Samsun'; T, 'Tekir'; Y, 'Yaglik'; M1, Lambda DNA/Hind III marker (vivantis); M2, 1kb ladder (GeneRulerTM), M3, 100bp ladder (GeneRulerTM); Cnt. (- Control), Some of polymorphic band profiles were shown with circles and arrows]

Table 1. LTR and ISSR primers (Martins-Lopes et al., 2009; Smykal et al., 2011)

\begin{tabular}{|c|c|c|c|c|c|}
\hline $\begin{array}{l}\text { LTR } \\
\text { Primers }\end{array}$ & Sequence 5'-3' & $\begin{array}{l}\text { Gene Bank } \\
\text { accession } \\
\text { number }\end{array}$ & ISSR Primers & Sequence 5'-3' & $\begin{array}{l}\text { Gene Bank } \\
\text { accession } \\
\text { number }\end{array}$ \\
\hline LTR 1 & $\begin{array}{l}\text { ACCCCTTGAGCTAACTTTTGGGGTAAG } \\
\end{array}$ & GU735096 & ISSR 1 & $(\mathrm{AG})_{8} \mathrm{~T}$ & UBC 807 \\
\hline LTR 2 & CTTGCTGGAAAGTGTGTGAGAGG & GU929874 & ISSR 2 & $(\mathrm{AG})_{8} \mathrm{G}$ & UBC 809 \\
\hline LTR 3 & TGTTAATCGCGCTCGGGTGGGAGCA & DQ767972 & ISSR 3 & $(\mathrm{GA})_{8} \mathrm{~T}$ & UBC 810 \\
\hline LTR 4 & AGCCTGAAAGTGTTGGGTTGTCG & GU980589 & ISSR 4 & $(\mathrm{GA})_{8} \mathrm{C}$ & UBC 811 \\
\hline LTR 5 & CTGGCATTTCCATTGTCGTCGATGC & GU980588 & ISSR 5 & $(\mathrm{CA})_{8} \mathrm{~A}$ & UBC 817 \\
\hline LTR 6 & GCATCAGCCTGGACCAGTCCTCGTCC & GU929878 & ISSR 6 & $(\mathrm{TC})_{8} \mathrm{C}$ & UBC 823 \\
\hline LTR 7 & CACTTCAAATTTTGGCAGCAGCGGATC & GU735096 & ISSR 7 & $(\mathrm{AC})_{8} \mathrm{C}$ & UBC 826 \\
\hline LTR 8 & TCGAGGTACACCTCGACTCAGG & GU929877 & ISSR 8 & $(\mathrm{AG})_{8} \mathrm{CTT}$ & UBC 846 \\
\hline LTR 9 & АTTCTCGTCCGCTGCGCCCCTACA & GU980590 & ISSR 9 & $(\mathrm{CA})_{8} \mathrm{AGT}$ & UBC 855 \\
\hline LTR 10 & TGAGTTGCAGGTCCAGGCATCA & GU980587 & ISSR 10 & $(\mathrm{GT})_{8} \mathrm{CTA}$ & UBC 856 \\
\hline
\end{tabular}

Table 2. REMAP primer combinations

\begin{tabular}{|c|c|c|c|}
\hline & Primer Combination & & Primer Combination \\
\hline REMAP 1 & LTR 1 and ISSR 1 & REMAP 11 & LTR2 and ISSR 2 \\
\hline REMAP2 & LTR 1 and ISSR 2 & REMAP 12 & LTR 3 and ISSR 3 \\
\hline REMAP3 & LTR 1 and ISSR 3 & REMAP 13 & LTR 4 and ISSR 4 \\
\hline REMAP 4 & LTR 1 and ISSR 4 & REMAP 14 & LTR 5 and ISSR 5 \\
\hline REMAP5 & LTR 1 and ISSR 5 & REMAP 15 & LTR 6 and ISSR 6 \\
\hline REMAP 6 & LTR 1 and ISSR 6 & REMAP 16 & LTR7 7 and ISSR 7 \\
\hline REMAP7 & LTR 1 and ISSR 7 & REMAP 17 & LTR 8 and ISSR 8 \\
\hline REMAP 8 & LTR 1 and ISSR 8 & REMAP 18 & LTR9 and ISSR9 \\
\hline REMAP9 & LTR 1 and ISSR 9 & REMAP 19 & LTR 10 and ISSR 10 \\
\hline REMAP 10 & LTR 1 and ISSR 10 & & \\
\hline
\end{tabular}

cultivars 'Canino' and 'Frantoio' (similarity ranges from 0.245 to 0.379). On the contrary, B1-5, Balikesir cv. 'Edincik' (Cluster I) indicated independent branches from the other cultivars (Fig. 1) and this cultivar had many polymorphic bands in the most of PCR gel analysis (Fig. 5A). On the other hand, the combined dendrograms indicated that clones Y1, 2 and 3 (Cluster III) and Y4 and 5 (Cluster $I V)$ of cv. 'Yaglik' were in different groups. This was not surprising as there were many polimorfic bands in PCR gel analysis (Fig. 5B).
Retrotransposon-based marker techniques have been extensively used to determinate genetic relationships between numerous plant species and cultivars (Queen et al., 2004; Branco et al., 2007; Agarwal et al., 2008; Vukich et al., 2009; D’Onofrio et al., 2010). However, there have been a few reports on olive cultivar identification via retrotransposon-based marker techniques and one of them used SCAR marker (Hernández et al., 2001). Accordingly, the present report will be the first comprehensive study on molecular characterization of olive cultivars using both IRAP and REMAP molecular markers. All primers gave obvious amplification patterns. The co-dominant nature of these markers detected to higher levels of expected heterozygosity.

Although the two marker systems produced different cluster numbers in all cultivars according to the dendrogram analyses, high compatibility was obtained from both and their polymorphism rate was very similar ( $96.82 \%$ for IRAP and $97.52 \%$ for REMAP). The high level of polymorphism was detected with B1-5, Balikesir cv. 'Edincik' by both the two marker systems; indeed this cultivar was very distant from the others and was grouped into different cluster (it 
172

was seen in "Cluster I" for three dendrograms). This cultivar is very different from the others also for the morphological characteristics; it has relatively bigger fruits, low oil and high water content (Isik et al., 2011).

The dendrogram analyses almost fully matched with same clones, however there was some evidence for clustering of clones derived from different branches. Clone (cv. 'Yaglik') Y1-3 and Y4-5 were in different groups and their similarity ranges were between 0.419 and 0.480 . These differences could be the result of crosspollination with local populations (Contento et al., 2002), somatic mutations (Belaj et al., 2004), and sometimes could also be due to the presence of a high level of homonymy in the collection. This is a significant problem and is a great risk for olive producers, as the renewal of certified orchards should be based on certified plants (Gemas et al., 2004; Martins-Lopes et al., 2007; Hannachi et al., 2008). However, classical olive certification system is based on morphological and agronomic procedures, which are affected by the environmental conditions, and mislabeling accessions can negatively affect certification of olive products (Hannachi et al., 2008). Molecular marker systems are of great importance to overcome such problem, and is necessary to determine the polymorphism level of olive cultivars and homonymy and synonym problems in olive germplasm. High values of observed heterozygosity were recorded for all the IRAP and REMAP markers investigated.

Determination of genetic relationships among cultivars eases efficient sampling, operating and using of germplasm resources. In the present study, IRAP and REMAP analysis displayed a high level of genetic variability among olive cultivars, indicating a potential resource for the use of this germplasm in clonal selection programs.

\section{Acknowledgments}

The study was supported by Mugla Sitki Kocman University, Scientific Research Projects Coordination Unit (Mugla, Turkey, MSKU-BAP 15-005) and Gebze Technical University, Molecular Biology and Genetics Department, Plant Biotechnology Laboratory (Kocaeli, Turkey).

\section{Conflict of interest}

The authors declare that they have no conflict of interest.

\section{References}

Agarwal M, Shrivastava N, Padh H (2008). Advances in molecular marker techniques and their applications in plant sciences. Plant Cell Reports 27:617-631.

Albertini E, Torricelli R, Bitocchi E, Raggi L, Marconi G, Pollastri L, Di Minco G, Battistini A, Papa R, Veronesi F (2011). Structure of Genetic Diversity in Olea europaea L. Cultivars from Central Italy. Molecular Breeding 27:533-547.

Angiolillo A, Mencuccini M, Baldoni L (1999). Olive genetic diversity assessed using amplified fragment length polymorphisms. Theoretical and Applied Genetics 98:411-421.

Atienza SG, De la Rosa R, Domínguez-García MC, Martín A, Kilian A, Belaj A (2013). Use of DArT Markers as a Means of Better Management of the Diversity of Olive Cultivars. Food Research International 54:2045-2043.
Awan AA, Zubair M, Iqbal A, Abbas SJ, AliN (2011). Molecular Analysis of Genetic Diversity in Olive Cultivars. African Journal of Agricultural Research 6(21):4937-4940.

Beiki AH,Saboor S, Ebrahimi M (2012). A new avenue for classification and prediction of olive cultivars using supervised and unsupervised algorithms. PloSONE7(9), e44164.

Belaj A, Rallo L, Trujillo I, Baldoni L (2004). Using RAPD and AFLP markers to distinguish individuals obtained by clonal selection of 'Arbequina' and 'Manzanila de Sevilla' olive. HortScience 39:15661570.

Belaj A, Munoz-Diez C, Baldoni L, Satovic Z, Barranco D (2010). Genetic Diversity and Relationships of Wild and Cultivated Olives at Regional Level in Spain. Scientia Horticulturae 124:323-330.

Biswas MK, Xu Q, Deng X (2010). Utility of RAPD, ISSR, IRAP and REMAP markers for the genetic analysis of Citrus spp. Scientia Horticulturae 124:254261.

Branco CJ, Vieira EA, Malone G, Kopp MM, Malone E, Bernardes A, Mistura CC, Carvalho FI, Oliveira CA (2007). IRAP and REMAP assessments of genetic similarity in rice. Journal of Applied Genetics 48(2):107-13.

Bronzini de Caraffa V, Giannettini J, Gambotti C, Maury J (2002). Genetic relationships between cultivated and wild olives of Corsica and Sardinia using RAPD markers. Euphytica 123(2):263-271.

Cabo S, Carvalho A, Rocha L, Martin A, Lima-Brito J (2014). IRAP, REMAP and ISSR Fingerprinting in Newly Formed Hexaploid Tritordeum (X Tritordeum Ascherson et Graebner) and Respective Parental Species. Plant Molecular Biology Reporter 32(3):761-770.

Cicatelli A, Fortunati T, De Feis I, Castiglione S (2013). Oil Composition and Genetic Biodiversity of Ancient and New Olive (Olea europea L.) Varieties and Accessions of Southern Italy. Plant Science 210:82-92.

Contento A, Ceccarelli M, Gelati M, Maggini F, Baldoni L, Cionini P (2002). Diversity of Olea genotypes and the origin of cultivated olives. Theoretical and Applied Genetics 104:1229-1238.

Corrado G, Imperato A, La Mura M, Perri E, Rao R (2011). Genetic Diversity Among Olive Varieties of Southern Italy and the Traceability of Olive Oil Using SSR Markers. The Journal of Horticultural Science and Biotechnology 86(5):461-466.

Diaz A, Martin A, Rallo P, De la Rosa R (2006). Self- and crossincompatibility mechanisms: a strategy to ensure a great variability in olive (Olea europaea L.) populations. Olea 25:29-33.

D’Onofrio C, De Lorenzis G, Giordani T, Natali L, Cavallini A, Scalabrelli G (2010). Retrotransposon-based molecular markers for grapevine species and cultivars identification Tree Genetics and Genomes 6:451466.

Doyle, J.J., Doyle, J.L. (1987). A rapid DNA isolation procedure for small quantities of fresh leaf tissue. Focus 12:13-15.

Figueiredo E, Canhoto J, Ribeiro MM (2013). Fingerprinting and Genetic Diversity of Olea europaea L. ssp. europaea Accessions from the Cultivar Galega Using RAPD Markers. Scientia Horticulturae 156:24-28.

Fiorino P, Rallo L (1999). Proceedings of the International Seminar Genetic Resources. Florence, Italy pp 1-24.

Flavell AJ, Dunbar E, Anderson R, Pearce SR, Hartley R, Kumar A (1992). Tyl-copia group retrotransposons are ubiquitous and heterogeneous in 
higher plants. Nucleic Acids Research 20:3639-3644.

Gemas VJV, Almadanim MC, Tenreiro R, Martins A, Fevereiro P (2004). Genetic diversity in the Olive tree (Olea europaea L. subsp. europaea) cultivated in Portugal revealed by RAPD and ISSR markers. Genetic Resources and Crop Evolution 51:501-511.

Giordani T, Buti M, Maestrini P, Cavallini A, Natali L (2004). Use of Tylcopia retrotransposons to study genetic diversity in olive (Olea europaea L.) cultivars. In: De Bellis L, Filippone E, Romani G (Eds). Proceedings of the XIVIII Italian Society of Agricultural Genetics SIFV-SIGA). Galatina, Lecce, Italy pp 195-196.

Gomes S, Martins-Lopes P, Lima-Brito J, Meirinhos J, Lopes J, Martins A, Guedes-Pinto H (2008). Evidence of Clonal Variation in Olive 'Verdeal-Transmontana' Cultivar Using RAPD, ISSR and SSR Markers. Journal of Horticultural Science and Biotechnology 83(4):395-400.

Grati-Kamoun N, Lamy Mahmoud F, Rebai A, Gargouri A, Panaud O, Saar A (2006). Genetic Diversity of Tunisian Olive Tree(Olea europaea L.) Cultivars Assessed by AFLP Markers. Genetic Resources and Crop Evolution 53:265-275.

Green PS (2002). A revision of Olea L. (Oleaceae). Kew Bulletin 57:91-140.

Hannachi H, Breton C, Msallem M, Ben El HadjS, El Gazzah M, BervilléA (2008). Differences between native and introduced olive cultivars as revealed by morphology of drupes, oil composition and SSR polymorphisms: a case study in Tunisia. Scientia Horticulturae 116:280290.

Hernández P, de la Rosa R, Rallo L, Martín A, Dorado G (2001). First evidence of a retrotransposon-like element in olive (Olea europaea): implications in plant variety identification by SCAR-marker development. Theoretical and Applied Genetics 102:1082-1087.

Hess J, Kadareit JW, Nargas P (2000). The colonization history of Olea europaea L. in Macaronesia based on internal transcribed spacer 1 (ITS1) sequences, randomly amplified polymorphic DNAs (RAPD), and inter simple sequence repeats (ISSR). Molecular Ecology 9:857-868.

Isik N, Doganlar S, Frary A (2011). Genetic Diversity of Turkish Olive Varieties Assessed by Simple Sequence Repeat and Sequence-Related Amplified Polymorphism Markers. CropScience 5:1646-1654.

Kalendar R, Flavell AJ, Ellis THN, Sjakste T, Moisy C, Schulman AH (2011). Analysis of plant diversity with retrotransposon-based molecular markers. Heredity 106:520-530.

Kalendar R, Grob T, Regina M, Suoniemi A, Schulman A (1999). IRAP and REMAP: two new retrotransposon-based DNA fingerprinting techniques. Theoretical and Applied Genetics 98:704711.

Kalendar R, Schulman HA (2006). IRAP and REMAP for retrotransposon-based genotyping and fingerprinting. Nature Protocols 1(5):2478-2484.

Kalendar R, Tanskanen J, Immonen S, Nevo E, Schulman AH (2000). Genome evolution of wild barley (Hordeum spontaneum) by BARE-1 retrotransposon dynamics in response to sharp microclimatic divergence. Proceedings of the National Academy of Sciences 97(12):6603-6607.

Kaya E, Yilmaz-Gokdogan, E (2015). Molecular Characterization OfSome Turkish Olive Cultivars Using Random Amplified Polymorphic DNA (RAPD) Markers. Suleyman Demirel University Journal of Natural and Applied Science 19(1):103-106.

Koksal B, Kaya E, Efe K, Uzan B, Ozden-Ciftci Y (2014). Molecular Characterization of Some Turkish Olive (Olea europaea L.) cultivars based on IRAP Markers. 2014 World Forum on Biology, Joint Meeting of the Society for In Vitro Biology and the Society for Cryobiology. Savannah, Georgia, USA Vol 50 p 54.

Kumar A (1996). The adventures of the Tyl-Copia group of retrotransposons in plants. Trends Genetics 12:41-43.

Kumar A, Bennetzen J (1999). Plant retrotransposons. Annual Review of Genetics 33:479-532.

LuchettiF(1993). The international olive oil trade. Olivae 45:16-18.

Martins-Lopes P, Lima-Brito J, Gomes S, Meirinhos J, Santos L, GuedesPinto H (2007). RAPD and ISSR Molecular Markers in Olea europaea L.: Genetic Variability and Cultivar Identification. Genetic Resource and CropEvolution 54:117-128.

Martins-Lopes P, Gomes S, Lima-Brito J, Lopes J, Guedes-Pinto H (2009). Assessment of Clonal Genetic Variability in Olea europaea L. 'Cobrançosa' by Molecular Markers. Scientia Horticulturae 123:82-89.

Montemurro C, Pasqualone A, Simeone R, Sabetta W, Blanco A (2008). AFLP molecular markers to identify virgin olive oils from single Italian cultivars. European Food Research and Technology 226(6):1439-1444.

Muzzalupo I, Stefanizzi F, Perri E (2009). Evaluation of Olives Cultivated in Southern Italy by Simple Sequence Repeat Markers. HortScience 44(3):582-588.

Queen RA, Gribbon BM, James C, Jack P, Flavell AJ (2004). Retrotransposon-based molecular markers for linkage and genetic diversity analysis in wheat. Molecular Genetics and Genomics 271:9197.

Pagnotta MA, Mondini L, Porceddu E (2009). Quantification and organization of WIS2-1A and BARE-1 retrotransposons in different genomes of Triticum and Aegilops species. Molecular Genetics and Genomics 282:245-255.

Reale S, Doveri S, Diaz A, Angiolillo A, Lucentini L, Pilla F, Martín A, Donini P, Lee D (2006). SNP-Based Markers for Discriminating Olive (Olea europaea L.) Cultivars. Genome 49(9):1193-1205.

Rugini E, Lavee S (1992). Olive. In: Hammerschlag FA, Litz RE (Eds). Biotechnology of Perennial Fruit Crops. CAB Int Wellingford UK pp 371-382.

Sharma V, Nandineni MR (2014). Assessment of genetic diversity among Indian potato (Solanum tuberosum L.) collection using microsatellite and retrotransposon based marker systems, Molecular Phylogenetics and Evolution 73:10-17.

Shedlock AM, Okada N (2000). SINE insertions: Powerful tools for molecular systematics. Bioessays 22:148-160.

Smykal P, Bacova-Kerteszova N, Kalendar R, Corander J, Schulman AH, Pavelek M (2011). Genetic diversity of cultivated flax (Linum usitatissimum L.) germplasm assessed by retrotransposon-based markers. Theoretical and Applied Genetics 122:1385-1397.

Suoniemi A, Tanskanen J, Schulman AH (1998). Gypsy-like retrotransposons are widespread in the plant kingdom. Plant Journal 13:699-705.

Vicient CM, Kalendar R, Schulman AH (2001). Envelope-Class Retrovirus-Like Elements Are Widespread, Transcribed and Spliced, 
174 and Insertionally Polymorphic in Plants. Genome Resources 11(12):2041-2049.

Vukich M, Schulman AH, Giordani T, Natali L, Kalendar R, Cavallini A (2009). Genetic variability in sunflower (Helianthus annuus L.) and in the Helianthus genus as assessed by retrotransposon-based molecular markers Theoretical and Applied Genetics 119:1027-1038.

Yuying S, Xiajunb D, Fei W, Binhuaa C, Zhihonga G, Zhena Z (2011). Analysis of genetic diversity in Japanese apricot (Prunus mume Sieb. et Zucc.) based on REMAP and IRAP molecular markers. Scientia Horticulturae 132:50-58.
Zohary D, Hopf M (1994). Domestication of plants in the Old World, 2nd edn. Clarendon Press, Oxford, UK.

Zitoun B, Bronzini de Caraffa V, Giannettini J, Breton C, Trigui A, MauryJ, Gambotti C, Marzouk B, Berti L (2008). Genetic Diversity in Tunisian Olive Accessions and Their Relatedness with Other Mediterranean Olive Genotypes. Scientia Horticulturae 115:416-419. 